$14^{\text {th }}$ Conf. Agric. Develop. Res., Fac. of Agric., Ain Shams Univ.,

March, 2019, Cairo, Egypt

Special Issue, 27(1), 323 - 328, 2019

Website: http://strategy-plan.asu.edu.eg/AUJASCl/

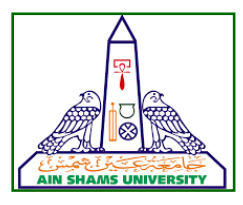

323

\title{
EFFECT OF RUMINAL BACTERIA (ZAD) ON CHEMICAL COMPOSITION OF ROUGHAGES
}

\author{
Amira M. Abd El Maksoud ${ }^{1^{*}}$, Metwally ${ }^{2}$ H.M., Gado ${ }^{2}$ H.M. and \\ EL-Gaziry ${ }^{1}$ A. A.
}

1. Animal Nutrition Dept., Animal Production Research Institute, Dokki, Giza, Egypt.

2. Animal Production of Dept., Fac. of Agric., Ain Shams Univ., P.O. 68 Hadayek Shobra 11241, Cairo, Egypt.

*Corresponding author: amira_m_abd@yahoo.com

Received 21 October, 2018,

Accepted 30 October, 2018

\section{ABSTRACT}

Four common Egyptian Agricultural by products used for ruminant feeding were treated with different concentrations of Probiotic (ZAD) to study the effect of treatment on chemical composition of roughages. Roughages used were rice straw (RS), wheat straw (WS), corn stover (CS) and sugar cane bagasse (SCB). Concentrations of ZAD tested in this study were $0.05,1.0,1.5$ and $2 \mathrm{ml} / \mathrm{Kg}$ of roughage.

Roughages were mixed with ZAD solution and incubated anaerobically for 4 weeks. Results indicated that treatments decreased crude fiber (CF) contents of all roughages by $17 \%$ in CS to $30 \%$ in SCB and increased EE by multiplication of 1.45 times in WS to 4.9 times in SCB. Statistical analysis showed no significant interaction between roughage source and ZAD concentration on chemical composition of roughages except for crude protein where interaction was significant $(P<.05)$. Results also indicated that ZAD concentration over $0 \mathrm{ml} / \mathrm{kg}$ affected CF \& CP contents, it was also noticed that $\mathrm{CP}$ of RS showed the highest response for treatment followed by SCB and CS, respectively. Crude protein of WS was not affected by different ZAD concentration. It was concluded that $Z A D$ concentration of $1 \mathrm{ml} / 1 \mathrm{Kg}$ of roughage is recommended for treatment to improve roughage chemical analysis.

Keywords: Chemical composition, Ruminant, ZAD, rice straw, wheat straw, corn stalls, sugar cane bagasse.

\section{INTRODUCTION}

Many agricultural by-products have been used in ruminant nutrition for a long time in Egypt. Rice straw, wheat straw, corn stover and bagasse are common agricultural by products in Egypt. They are usually used to feed ruminant animals as low quality roughages because of their low nutritive value, high fiber and legnocellulose content (Leng 1991). They are also low in minerals, especially phosphorus, insufficient in crude protein and deficient in vitamins (Tingshuang et al 2002). Several digestibility experiments and feeding trials have been conducted to study the effect of nutritive value of crop residues on digestibility (Khattab et al 2008; Kholif et al 2014). It has been concluded that high fiber contents negatively affect voluntary intake and rate of organic matter fermentation and feeding such residues without treatment or untreatment supplementation, can just or barely cover maintenance energy requirement.

Several methods have been suggested for improving feeding value of agricultural by-products. Ensiling of many dry crop by-products have been used with addition of microorganisms and/or enzymes after chopping, reconstitution of moisture and processing then saved in an anaerobic condition (Nahla et al 2014).

Objective of the present study was to investigate the effect of treating different roughages with different ZAD concentration on its chemical composition. 


\section{MATERIALS AND METHODS}

The present study was performed from November 2015 to May 2018, at the Animal Production Research Institute (APRI) and Faculty of Agriculture, Ain Shams University, Cairo, Egypt.

\section{Raw material}

Bagasse (SCB), Rice straw (RS), Corn stov$\operatorname{er}(\mathrm{CS})$, wheat straw(WS), molasse, and urea were obtained from Farm of faculty of Agriculture- Ain Shams University. Strain Lactobacillus was obtained from Microbial Resources Centre - Faculty of Agriculture - Ain Shams University (MRC). media rumen fluid was obtained from Slaughterhouse..

\section{Chemicals}

All chemicals used throughout this work were biochemical grades from (APRI) Sigma, Chemicals Company.

\section{Preparation of compost solution}

Molasse and urea were added at the rate of $10 \%$ and $2 \%$ respectively, then added amount of water to raise the humidity to $60 \%$ for feed materials used.

\section{Composting}

The humidity of the bagasse, straw and corn stover was determined by drying $2 \mathrm{gm}$ of each substance on $105^{\circ} \mathrm{C}$ for 3 hours until the stability of weight. 75 samples of each material was prepared, where the sample weighes $250 \mathrm{gm}$. Then compost solution was mixed with the Bagasse, straws and corn stover.

Composting samples was carried out well in order to enable bacteria to grow and reproduce anaerobically, leaving samples at room temperature. Then takeing a representative sample $(2 \mathrm{gm})$ of each repeat for chemical analyses.

Approximate analyses were conducted according to (AOAC 1995). Fiber fraction were determined according to (Vansoest et al 1991).

\section{Statistical Analyses}

Data were statistically analyzed using the general linear model procedure (SAS 2002). The dif- ferences among means tested using Duncan's multiple-rang test (Duncan 1995).

\section{The statistical model was as follw}

$$
Y_{i e j}=\mu+S_{i}+C_{e}+S C_{i e}+e_{i e j}
$$

Where:

$Y_{i e j}=$ an observation

$\mu=$ overall means

$\mathrm{S}_{\mathrm{i}}=$ effect of roughage source

$\mathrm{C}_{\mathrm{e}}=$ effect of $\mathrm{ZAD}$ concentration

$S \mathrm{C}_{i \mathrm{e}}=$ effect of interaction between roughage source and ZAD concentrations

$\mathrm{e}_{\mathrm{iej}}=$ random error .

\section{RESULTS AND DISCUSSION}

\section{Chemical Composition of Roughages used in the present study}

Chemical Composition of Roughages used in the present study is shown in Table (1): Dry matter (DM) content of rice straw, wheat straw and corns stover were more than $95.5 \%$ with very tiny differences, however sugar cane bagasse (SCB) had the lowest DM contents (93.5\%).

Crude Protein(CP) content was the highest in corn stover $(5.52 \%)$ and the lowest in SCB $(1.34 \%)$, while rice straw (RS) and wheat straw were intermediated $(3.76,2.85 \%$ respectively).

Ether extract values (EE) as an indicator for lipid content of roughages were the highest $(1.37 \%)$ in WS followed by (RS) $(0.88 \%)$ and CS $(0.53 \%)$ while SCB had the lowest EE contents $(0.38 \%)$ among all tested roughages.

Sugar cane bagasse contained the highest CF $(45.63 \%)$ compared with $(40.21 \%)$ for WS (38.58\%) for RS and $38.38 \%$ for CS.

Results obtained in the present study were similar to those reported by Mohamed et al 2016, Ibrahim et al 2017. Gomaa et al 2016 and Safa et al 2011. Crude protein in $\mathrm{RS}$ ranged between $3.41 \%$ (Ibrahim et al 2017) and 3.9 (Safa et al 2011) agreeing with the present study (3.76\%). Same trend of agreement was noticed for CF. However, for (WS) refrences reported a wide range for (CP); where Salama et al 2011 reported a value of $5.7 \%$, Sharifi Hosseini et al 2015 recorded $1.42 \%$ and Hassan \& Nisa 2011 reported 2.90. This wide range may be due to using different cultivars of wheat with different agricultural processing to raise wheat. Crude protein of CS in the present 
study $(5.52 \%)$ was very clause to that obtained by Safa et al 2011 (4.95\%) who reported a value of $34.97 \%$ for CF in CS compared to $38.38 \%$ in the present study. Values obtained in the present study for CP \& CF of SCB $(1.34,45.63$ respectively) were comparable to those obtained by several investigators (Nahla et al 2014, Gado et al 2007 and Salama et al 2011).

Table 1. Chemical composition of roughages (Rice straw, Wheat straw, Corn stover, Bagasse)

\begin{tabular}{|c|c|c|c|c|c|c|}
\hline Items & DM & CP & EE & CF & NFE & Ash \\
\hline RS & 95.5 & 3.76 & 0.88 & 38.58 & 41.46 & 15.32 \\
WS & 96.2 & 2.85 & 1.37 & 40.21 & 46.04 & 9.53 \\
CS & 96.5 & 5.52 & 0.53 & 38.38 & 45.22 & 10.35 \\
SCB & 93.5 & 1.34 & 0.38 & 45.63 & 41.9 & 10.75 \\
\hline
\end{tabular}

\section{Effect of ZAD treatments on chemical composi- tion of experimental roughages}

Data in Table (2) showed the effect of treatment with AZD on chemical composition of experimental roughages used in the present study. Results indicated that treatment lowered CF contents by $27 \%$ in RS, $17 \%$ in WS, $27 \%$ in CS and $30 \%$ in SCB. ZAD treatment increased EE content of RS, WS, CS and SCB by multiplications of $2.87,1.45$, 4.7 and 4.9 times, respectively.

Results obtained in the present study were in agreement with those reported by Ibrahim et al 2017, who stated that treating RS with ZAD decreased CF content of RS from $38.33 \%$ to $31.08 \%$ and increased EE from $1.20 \%$ up to $1.78 \%$. Results in Table (2) also indicated that hemicellulose, cellulose and lignin were similar for RS \& WS but they were significantly lower $(P<0.05)$ in $C S$ and SCB.

Table 2. Effect of roughages sources on chemical composition (on DM basis)

\begin{tabular}{|c|c|c|c|c|c|c|c|c|}
\hline Item & DM & CF & EE & NFE & ASH & Hemi & Celi & Leg \\
\hline RS & $40.86 \pm 0.21$ & $27.92 \pm 0.24 \mathrm{c}$ & $2.53 \pm 0.12 \mathrm{a}$ & $39.78 \pm 0.32 \mathrm{c}$ & $15.19 \pm 0.09 \mathrm{a}$ & $30.85 \pm 0.30 \mathrm{a}$ & $34.71 \pm 0.34 \mathrm{a}$ & $6.03 \pm 0.23 \mathrm{a}$ \\
WS & $40.89 \pm 0.24$ & $33.35 \pm 0.37 \mathrm{a}$ & $1.98 \pm 0.11 \mathrm{~b}$ & $41.60 \pm 0.23 \mathrm{~b}$ & $10.54 \pm 0.09 \mathrm{c}$ & $30.36 \pm 0.23 \mathrm{a}$ & $34.16 \pm 0.33 \mathrm{a}$ & $6.03 \pm 0.23 \mathrm{a}$ \\
CS & $40.83 \pm 0.13$ & $27.97 \pm 0.34 \mathrm{c}$ & $2.48 \pm 0.21 \mathrm{a}$ & $47.08 \pm 0.48 \mathrm{a}$ & $12.11 \pm 0.27 \mathrm{~b}$ & $28.08 \pm 0.33 \mathrm{c}$ & $34.05 \pm 0.41 \mathrm{a}$ & $5.59 \pm 0.26 \mathrm{ab}$ \\
SCB & $41.08 \pm 0.15$ & $31.76 \pm 0.33 \mathrm{~b}$ & $1.87 \pm 0.12 \mathrm{~b}$ & $47.87 \pm 0.40 \mathrm{a}$ & $10.90 \pm 0.24 \mathrm{c}$ & $29.11 \pm 0.28 \mathrm{~b}$ & $31.28 \pm 0.33 \mathrm{~b}$ & $5.27 \pm 0.17 \mathrm{~b}$ \\
\hline
\end{tabular}

$a, b$ and $c$ : means within each column with different superscripts are significantly differ $(p<0.05)$.

$1 \mathrm{R}:$ Rice straw. 2R: Wheat straw. 3R: Corn Stover. 4R: Bagasse.

\section{Effect of ZAD concentration on chemical com- position of experimental roughages}

Results in Table (3) showed the effect of ZAD concentration on chemical composition of treated roughages. Results indicated that treatment (1) (zero ZAD $0.2 \%$ Urea and $10 \%$ molasses) decreased CF contents of all roughages from $40.7 \%$ (over all mean of all tested roughages) to $31.95 \%$. However, $0.5 \mathrm{ml}$ of ZAD per $1 \mathrm{Kg}$ roughage did not affect CF contents significantly. On the other hand ZAD concentration of $1,1.5$ and $2 \mathrm{ml} / \mathrm{kg}$ decreased CF contents significantly compared with zero concentration with no significant differences between different concentration.

Ether extract contents were increased by all ZAD concentrations compared with over all mean of untreated roughages $(0.79 \%)$, but there were no significant differences between different concentrations. 
Table 3. Effect of enzyme treatment on chemical composition of roughages (on DM basis)

\begin{tabular}{|c|c|c|c|c|c|c|c|c|}
\hline $\begin{array}{c}\text { Enzyme } \\
\text { concentration }\end{array}$ & DM & CF & EE & \multicolumn{1}{|c|}{ NFE } & \multicolumn{1}{|c|}{ ASH } & Hemi & Celi & Leg \\
\hline $\mathbf{0}$ & $41.14 \pm 0.24$ & $31.95 \pm 0.45 \mathrm{a}$ & $2.26 \pm 0.14$ & $43.93 \pm 0.62 \mathrm{ab}$ & $11.72 \pm 0.33 \mathrm{~b}$ & $30.04 \pm 0.31$ & $33.87 \pm 0.54$ & $6.05 \pm 0.33$ \\
$\mathbf{0 . 5}$ & $41.00 \pm 0.19$ & $30.33 \pm 0.4 \mathrm{ab}$ & $2.42 \pm 0.19$ & $43.61 \pm 0.56 \mathrm{~b}$ & $12.33 \pm 0.33 \mathrm{ab}$ & $29.81 \pm 0.40$ & $33.69 \pm 0.44$ & $5.79 \pm 0.22$ \\
$\mathbf{1}$ & $40.97 \pm 0.17$ & $30.27 \pm 0.52 \mathrm{~b}$ & $2.20 \pm 0.15$ & $43.52 \pm 0.65 \mathrm{~b}$ & $12.40 \pm 0.30 \mathrm{a}$ & $29.38 \pm 0.36$ & $33.32 \pm 0.39$ & $5.71 \pm 0.23$ \\
$\mathbf{1 . 5}$ & $40.62 \pm 0.22$ & $29.39 \pm 0.49 \mathrm{~b}$ & $2.11 \pm 0.18$ & $44.40 \pm 0.62 \mathrm{ab}$ & $12.49 \pm 0.36 \mathrm{a}$ & $29.64 \pm 0.38$ & $33.78 \pm 0.39$ & $5.72 \pm 0.24$ \\
$\mathbf{2}$ & $40.84 \pm 0.21$ & $29.31 \pm 0.54 \mathrm{~b}$ & $2.09 \pm 0.16$ & $44.97 \pm 0.77 \mathrm{a}$ & $12.00 \pm 0.36 \mathrm{ab}$ & $29.13 \pm 0.29$ & $33.08 \pm 0.42$ & $5.40 \pm 0.25$ \\
\hline
\end{tabular}

$a$ and $b$ : means within each column with different superscripts are significantly differ $(p<0.05)$.

Enzyme concentration: $\mathrm{ml} / \mathrm{kg}$.

\section{Effect of interaction between roughage sources and ZAD concentration on CP contents}

Results in Table (4) showed the effect of interaction between source of roughage and ZAD concentration on CP contents. Results indicated that CP of RS, CS and SCB increased significantly $(p<0.05)$ by all ZAD concentrations while CP of WS was not affected by any concentration. It was noticed that RS was the highest in its response to ZAD concentration followed by SCB and CS, respectively.

Similar results were obtained using $\mathrm{RS}$ treated with ZAD by Mohammed et al 2016. Safa et al 2011, reported a CP value of 9.45 when $R S$ was treated with fungus. However, Gomaa et al 2012, 2016 and Ibrahim et al 2017 recorded CP values of $7.95,6.08$ and $6.08 \%$, respectively.

Table 4. Effect of interaction between roughage sources and enzyme concentration on CP content of treated roughage

\begin{tabular}{l|l|l|l|l|l}
\hline $\mathbf{R}^{\star} \mathbf{E}$ & $\mathbf{1 E}$ & $\mathbf{2 E}$ & $\mathbf{3 E}$ & 4E & 5E \\
\hline $\mathbf{R S}$ & $8.34 \pm 0.33 \mathrm{c}$ & $11.98 \pm 0.25 \mathrm{a}$ & $11.96 \pm 0.25 \mathrm{a}$ & $11.87 \pm 0.31 \mathrm{a}$ & $12.29 \pm 0.24 \mathrm{a}$ \\
$\mathbf{W S}$ & $9.51 \pm 0.29 \mathrm{bc}$ & $9.85 \pm 0.17 \mathrm{bc}$ & $9.47 \pm 0.30 \mathrm{bc}$ & $10.17 \pm 0.33 \mathrm{~b}$ & $9.59 \pm 0.43 \mathrm{bc}$ \\
$\mathbf{C S}$ & $8.76 \pm 0.67 \mathrm{c}$ & $10.33 \pm 0.50 \mathrm{~b}$ & $10.55 \pm 0.69 \mathrm{~b}$ & $10.29 \pm 0.85 \mathrm{~b}$ & $10.86 \pm 0.81 \mathrm{~b}$ \\
SCB & $6.07 \pm 0.17 \mathrm{~d}$ & $8.76 \pm 0.16 \mathrm{c}$ & $8.56 \pm 0.19 \mathrm{c}$ & $8.507 \pm 0.23 \mathrm{c}$ & $8.95 \pm 0.31 \mathrm{c}$ \\
\hline
\end{tabular}

$a, b$ and $c:$ means within each column with different superscripts are significantly differ $(p<0.05)$ 1R: Rice straw. 2R: Wheat straw. 3R: Corn stover. 4R: Bagasse.

$1 \mathrm{E}: 0$ enzyme. $2 \mathrm{E}: 0.5 \mathrm{ml}$ enzyme. $3 \mathrm{E}: 1 \mathrm{ml}$ enzyme. $4 \mathrm{E}: 1.5 \mathrm{ml}$ enzyme. $5 \mathrm{E}: 2 \mathrm{ml}$ enzyme.

Similar results were obtained using $\mathrm{RS}$ tested with ZAD by Mohamed et al 2016. Safa et al 2011 reported a CP value of 9.45 when $\mathrm{RS}$ was treated with fungus. However, Gomaa et al 2012, 2016 and Ibrahim et al 2017 recorded CP values of $7.95,6.08$ and $6.08 \%$, respectively.

\section{CONCLUSION}

It can be concluded that treating roughages with $1 \mathrm{mlL}$ ZAD / $1 \mathrm{Kg}$ improved chemical composition of roughages used as ruminant feeds, However, more research is needed in order to determine the effect of treatment with ZAD on digestion, rumen fermentation and animal performance. 


\section{REFERECES}

AOAC, 1995. Official Methods of Analysis, $16^{\text {th }} \mathrm{Ed}$. Association of Official Analytical Chemists, Washington, DC, USA.

Duncan, D.B. 1955. Multiple rang and multiple $F$ tests. Biometrics, 11, 1-42.

Gado H.M., Metwally H.M., El-Basiony A.Z., Soliman H.S. and Etab R.I. Abd El-Galil 2007. Effect of biological treatments on sugarcane bagasse digestibility and performance of baladi goats. Egyptian J. Nutrition and Feeds, 10(2), 535-551.

Gomaa A.A.A.I., Mohamed M.Y., Fatma E. Saba, Ibrahim E.M.M., El-Badawy A.A. and ElGiziry A. A. 2016. Growth performance of ossimi lambs affected by treated rice straw by enzymes ZAD or effective microorganisms. Egyptian J. Nutrition and Feeds, 19(2), 243254.

Gomaa R., Gado H., EL-Sayed H. and Abd ElMawla S. 2012. Usage of treated rice straw with exogenous anaerobic bacterial enzymes (ZAD) for Ossimi Sheep. Annals of Agric. Sci., 57(2), 183-190.

Hassan Z., Nisa M., Shahzad M.A. and Sarwar M. 2011. Effects on Ruminal Characteristics, In situ Digestion Kinetics and Nitrogen Metabolism of Nili-Ravi Buffalo Bulls. Asian-Aust. J. Anim. Sci., 24(8), 1092-1099.

Ibrahim E.M.M., Gomaa A.A.A.I. and El-Giziry A.A. 2017. Effect of treating rice straw with ZAD enzymes or effective microorganisms on productive performance of ossimi ewes and their lambs. Egyptian J. of Sheep \& Goat Sci., 12(3), 37-47.

Khattab H.M., Sooud A.O., Salem A.M., Mansour A.M., Younan B.R. 2008. Agroindustrial by-products for feeding lactating goats. Egyptian J. of Nutrition and Feeds, 11, 145-158.

Kholif A.E., Khattab H.M., El-Shewy A.A., Salem A.Z.M., Kholif A.M., El-Sayed M.M., Gado H.M., Mariezcurrena M.D. 2014. Nutrient digestibility, ruminal fermentation activities, serum parameters and milk production and composition of lactating goats fed diets containing rice straw treated with Pleurotus ostreatus. Asian - Australasian J. of Animal Sci., 27, 357- 364.
Leng R.A. 1991. Application of biotechnology to nutrition of animals in developing countries. Rome, (C) FAO 1991. ISBN 92-5-103035-9

Mohamed M.Y., Gomaa A.A.A.I., Ibrahim E.M.M., Fatma E. Saba, El-Badawy A.A. and ElGiziry A.A. 2016. Sexual activity and reproductive performance of Ossimi sheep fed biologically treated rice straw by enzymes or effective microorganisms. Egyptian J. of Sheep \& Goat Sci., 11(3), 100-115.

Nahla A. Abdel-Aziz, Mounir El-Adawy, Maria A Mariezcurrena-Berasain, Abdelfattah Z.M. Salem, Jaime Olivares-Pérez, Ahmed E. Kholif and Borhami E. Borhami 2014. Effects of Exogenous Enzymes, Lactobacillus acidophilus or Their Combination on Feed Performance Response and Carcass Characteristics of Rabbits Fed Sugarcane Bagasse1. Journal of Integrative Agriculture Advance Online Publication, DOI: 10.1016/S20953119(14)60827-3.

Safa N. Abdel-Azim, Mona A. Ahmed, AboDonia F. and Soliman H. 2011. Evaluation of fungal treatment of some agricultural residues. Egyptian J. of Sheep \& Goat Sci., 6(2), 1-13.

Salama, R., Fatma M. Salman, Safwat M.A., Soliman S.M. and El-Nomeary Y.A. 2011. Chemical, Biological and Biochemical Treatments to Improve the Nutritive Values of Sugarcane Bagasse (SCB): 2- In Vivo Studies to Evaluate the Nutritive Values of Untreated and Treated SCB. Life Sci. J., 8(4), 327-337.

SAS 2002. Users Guide: Statistics version 9 edition SAS Institute, Cary, North Carolina, USA.

Sharifi Hosseini M.M., Dayani O. and Tahmasbi R. 2015. Effect of treatment of wheat straw with Pleurotus florida on feed intake, digestibility and body condition score in ewes. J. of Livestock Science and Technologies, 3(2), 2126.

Tingshuang Guo, Manuel D. Sánchez, Guo Pei Yu. 2002. Animal Production Based on Crop Residues - Chinese Experiences. FAO 2002. www.fao.org/docrep/005/y1936E/Y1936E00. HTM.

Van Soest P.J., Robertson J.B., Lewis B.A. 1991. Methods for dietary fibre, neutral detergent fibre, and non-starch carbohydrates in relation to animal nutrition. J. of Dairy Sci., 74, 3583-3597. 



\section{تأثير المعاملة ببكتريا الكرش (ZAD) عثل التركيب الكيميائي للأعلاف الخثنة}

$$
\begin{aligned}
& \text { أميرة محمد عبد المقصود13* - حمدي موسى متولي2 - هاني محمود جادو2 - - عمرو علي الجزيري } 1 \\
& \text { 1- قسم تغذية الحيوان - معهد بحوث الانتاج الحيوانى - الدقى - الجيزة - مصري }
\end{aligned}
$$

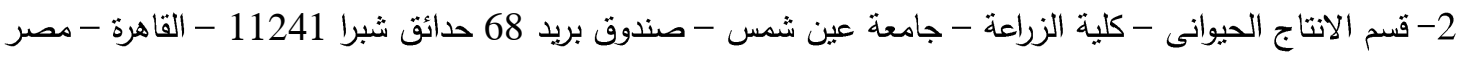

*Corresponding author: amira_m_abd@yahoo.com

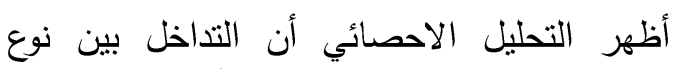
المخلف وتركيز ال ZAD لم يكن له تأثير معنوي على الفي التركيب الكيميائي للمخلفات إلا في المحتوى البروتيني ل للأعلاف.

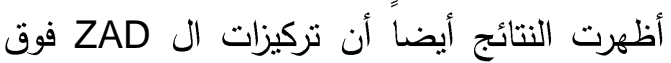

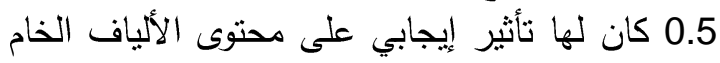

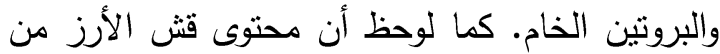

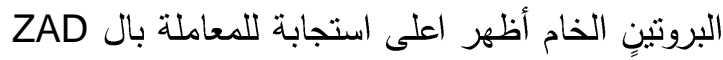

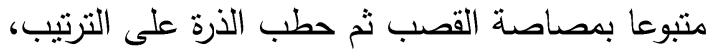
بينما لم يتأثر المحتوى البروتيني لتين القمح بالتركيزات

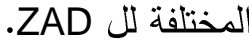

وخلصت نتائج هذه التجربة أن المعاملة بال ZAD تحت تركيز 1 ملليلتر / 1 كجم مخلف يمكن التوصية التهية بها لتحسين التركيب الكيميائي للمخلفات الزراعية لإنية المستخدمة في هذه التجربة.

الكلمات الدالة: التحليل الكميائى، المجترات، ZAD، قتش الارز، تبن القمح، حطب الاذره، مصاصة الترات،

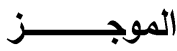

تم استخدام 4 أنواع مختلفة من المخلفات الزراعية المستخدمة في تغذية المجترات بعد معاملتها بتركيزات

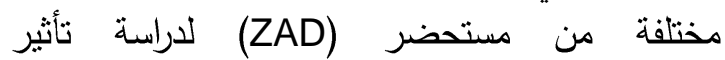
المستحضر على التركيب الكيميائي للمخلفات الممنلة

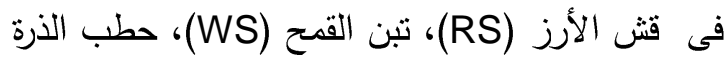

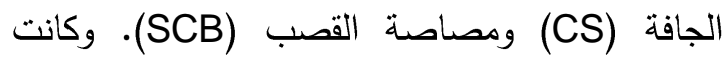
Zero, 0.5, 1, ) AZD التركيزات المختبرة من ال

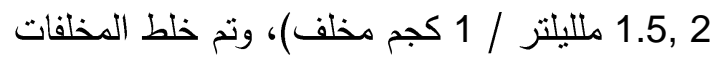
بمحلول ال ZAD، والتحضين تحت ظروف لاهوائية لمدة 4 أسابيع. أظهرت النتائج أن المعاملات خفضت محتوى

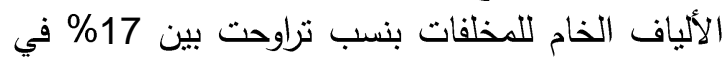
حطب الذرة و 30\% في مصاصة القصب كما تضاعف محتوى المستخلص الايثيري بقيم تراوحت بين

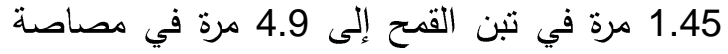

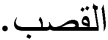

